\title{
Effect of different concentrations of soybean lecithin and virgin coconut oil in Tris-based extender on the quality of chilled and frozen-thawed bull semen
}

\author{
A. A. Tarig ${ }^{1,2}$, H. Wahid ${ }^{1}$, Y. Rosnina ${ }^{1}$, N. Yimer ${ }^{1}$, Y. M. Goh ${ }^{3}$, F. H. Baiee ${ }^{1}$, A. M. Khumran ${ }^{1}$, H. Salman ${ }^{1}$, \\ M. A. Assi ${ }^{3}$ and M. Ebrahimi ${ }^{3}$
}

1. Department of Veterinary Clinical Studies, Faculty of Veterinary Medicine, Universiti Putra Malaysia, UPM, 43400 Serdang, Selangor Darul Ehsan, Malaysia; 2. Department of Dairy Production, Faculty of Animal Production, University of Khartoum, Sudan; 3. Department of Veterinary Pre-Clinical Sciences, Faculty of Veterinary Medicine, Universiti Putra Malaysia, UPM, 43400 Serdang, Selangor Darul Ehsan, Malaysia.

Corresponding author: H. Wahid, e-mail: wahidh@upm.edu.my

Co-authors: AAT: tarignazar@hotmail.com, YR: rosninanuris@upm.edu.my, NY: nurdeg2006@gmail.com, YMG: ymgoh@upm.edu.my, FHB: falahhali@uokufa.edu.iq, AMK: khumranmada@yahoo.com, HS: hammadighareeb@gmail.com, MAA: razaq_assi@yahoo.com, ME: mehdiebrahimii@gmail.com

Received: 21-12-2016, Accepted: 05-05-2017, Published online: 20-06-2017

doi: 10.14202/vetworld.2017.672-678 How to cite this article: Tarig AA, Wahid H, Rosnina Y, Yimer N, Goh YM, Baiee FH, Khumran AM, Salman H, Assi MA, Ebrahimi M (2017) Effect of different concentrations of soybean lecithin and virgin coconut oil in Tris-based extender on the quality of chilled and frozen-thawed bull semen, Veterinary World, 10(6): 672-678.

\begin{abstract}
Aim: The objective of this study was to evaluate the effects of different concentrations of soybean lecithin (SL) and virgin coconut oil (VCO) in Tris-based extender on chilled and frozen-thawed bull semen quality parameters.

Materials and Methods: A total of 24 ejaculates were collected from four bulls via an electroejaculator. Semen samples were diluted with $2 \%$ VCO in Tris-based extender which consists of various concentrations of SL (1, 1.25, 1.5, and 1.75\%). A $20 \%$ egg yolk in Tris used as a positive control (C+). The diluted semen samples were divided into two fractions; one for chilling which were stored at $4^{\circ} \mathrm{C}$ for 24,72 , and $144 \mathrm{~h}$ before evaluated for semen quality parameters. The second fraction used for freezing was chilled for $3 \mathrm{~h}$ at $4^{\circ} \mathrm{C}$, packed into $0.25 \mathrm{~mL}$ straws and then cryopreserved in liquid nitrogen. The samples were then evaluated after 7 and 14 days. Chilled and frozen semen samples were thawed at $37^{\circ} \mathrm{C}$ and assessed for general motility using computer-assisted semen analysis, viability, acrosome integrity and morphology (eosin-nigrosin stain), membrane integrity, and lipid peroxidation using thiobarbituric acid reaction test.
\end{abstract}

Results: The results showed that all the quality parameters assessed were significantly $(\mathrm{p}<0.05)$ improved at $1.5 \%$ SL concentration in chilled semen. Treatment groups of $1,1.25,1.5$, and $1.75 \%$ SL were higher in quality parameters than the control group $(\mathrm{C}+)$ in chilled semen. However, all the quality parameters in frozen-thawed semen were significantly higher in the $\mathrm{C}+$ than the treated groups.

Conclusion: In conclusion, supplementation of 1.5\% SL in 2\% VCO Tris-based extender enhanced the chilled bull semen. However, there was no marked improvement in the frozen-thawed quality parameters after treatment.

Keywords: bull semen, cryopreservation, quality parameters, soybean lecithin, virgin coconut oil.

\section{Introduction}

The procedure of cryopreservation results in low semen quality that leads to reduced conception rate. Chilling temperatures are less detrimental to the intactness of the bull semen than freezing-thawing procedure, which results in more damage to the spermatozoa [1]. In New Zealand and Australia, studies have shown the opportunity of utilization and commercialization of chilled bull semen [2]. According to Verberckmoes et al. [2], in New Zealand, 95\% of the semen used for (artificial insemination [AI]) in cattle is processed as chilled semen. The major benefits linked to the utilization of cool-stored semen are a greater

Copyright: Tarig, et al. Open Access. This article is distributed under the terms of the Creative Commons Attribution 4.0 International License (http://creativecommons.org/licenses/by/4.0/), which permits unrestricted use, distribution, and reproduction in any medium, provided you give appropriate credit to the original author(s) and the source, provide a link to the Creative Commons license, and indicate if changes were made. The Creative Commons Public Domain Dedication waiver (http://creativecommons.org/ publicdomain/zero/1.0/) applies to the data made available in this article, unless otherwise stated. viability than frozen semen, the chance of consuming little doses for insemination, reduced expenses of storage, and the ease for utilizing in AI [3]. Moreover, chilled semen has more viability in the reproductive tract of female and guaranteeing greater rates of fertilization [4].

Egg yolk is commonly used in semen extenders; the ease of which egg yolk is affected by microbial contamination necessitates the development of alternatives to egg yolk in semen extenders. Consequently, efforts are aimed to develop chemically defined extenders, free of compounds that are of the animal sources [5]. Apart from being linked to microbial contamination, egg yolk extenders are known to interfere with the microscopic examination. Thus, replacement of such extender with plant source compound without compromising the desired qualities of perfect extender is very much warranted [6]. Thun et al. [7] and Aires et al. [8] who indicated that soybean lecithin (SL) has the same egg yolk components utilized for preventing animal semen from cold shock on frozen-thawed 
sperm. Moreover, according to Fukui et al. [9], who reported that SL might have a greater safety function for the sheep sperm than that of the egg yolk or other ingredients through cryopreservation procedure and thus, decrease the threat of introducing mycoplasma and bacteria in the frozen extenders. Singh et al. [1] showed that $25 \%$ soy milk based extender gave better quality parameters for bull semen at $5^{\circ} \mathrm{C}$ at different time interval. Zhang et al. [10] reported that the addition of $6 \%$ SL to the extender showed the best spermatozoa motility and plasma membrane integrity in frozen-thawed boar spermatozoa. SL is considered a better oil-in-water solvent in the candy industry [11].

Various additives such as antioxidants, fatty acids, and sugars have been added to reduce the damage of sperm through the frozen-thawed procedure [12-15]. One of these additives that is saturated and unsaturated fatty acids is contained in virgin coconut oil (VCO) [16]. Moreover, VCO has plenty of antioxidants such as tocotrienol, polyphenols, and tocopherols $[17,18]$. Since VCO is hydrophobic, it cannot dissolve in the extender. However, VCO can be emulsified with lecithin an excellent natural agent of emulsification [19]. To our knowledge, the use of VCO with SL in Tris-based extender and its effect on chilled and cryopreserved bull sperm has not been reported. Thus, this experiment was conducted to evaluate the effect of different concentrations of SL with $2 \%$ VCO in Tris-based extender on chilled and frozen-thawed quality parameters of bull semen.

\section{Materials and Methods \\ Ethical approval}

Approval for this study was given by the Institutional Animal Care and Use Committee of UPM with AUP No: R073/2015.

\section{Animals}

Semen samples were collected from four mature and fertile Brangus-Simmental crossbred bulls from the Universiti Putra Malaysia (UPM) Farm. Bulls aged about 5-6 years old and weighed about 640-650 kg. The four bulls were under a similar management of feeding with Brachiaria decumbens grass and commercial palm kernel cake which contains about $2.6 \%$ crude fat and $16 \%$ crude protein provided at an average of $3 \mathrm{~kg} / \mathrm{bull} /$ day. Mineral blocks and water were provided ad libitum. Semen collection and preparation of extenders

Ejaculates were collected from each bull twice per week, at 3 days interval by electroejaculation (Electrojac 6, USA). A total of 24 ejaculates were collected, and the samples were stored in a cooler box containing warm water at $37^{\circ} \mathrm{C}$ and transported to the laboratory for evaluations. Ejaculate samples collected with $\geq 80 \%$ normal sperm morphology, $\geq 70 \%$ general motility, and semen concentration of $\geq 500 \times 10^{6} / \mathrm{ml}[20]$ were included in the experiment. The semen samples were then extended with fraction one of the Tris (2.42 g) - citric (1.48 g) - fructose (1 g) extenders [21] as the main extender with different percentage of SL (SL P5638, Sigma-Aldrich, USA) $(0 \%, 1 \%, 1.25 \%, 1.5 \%$, and $1.75 \%)$ containing $2 \%$ VCO (VCO; manufactured by Nano Xan Sdn. Bhd and Malaysia Agriculture Research and Development Institute, Malaysia). The fraction one contains the main extender without glycerol; it was also used for chilled treatments. The other (fraction two) besides the basic extender contains glycerol $12.8 \mathrm{ml}$ for the frozen treatments. The treatment groups in chilled and frozen were divided into seven groups (Table-1). Semen sample was diluted to adjust the concentration of $20 \times 10^{6}$ sperm in a $0.25 \mathrm{ml}$ straw, subsequently gradually refrigerated to $4^{\circ} \mathrm{C}$ for $3 \mathrm{~h}$. Straws were stuffed with diluted semen (at $4^{\circ} \mathrm{C}$ ) and kept at the same temperature for $4 \mathrm{~h}$ to equilibrate. Filled straws of diluted semen were then cryopreserved in liquid nitrogen. In the freezing step, the straws were put on racks and placed horizontally $4 \mathrm{~cm}$ above the surface of the liquid nitrogen for $10 \mathrm{~min}$. The racks were left to plunge with the straws on liquid nitrogen for $3 \mathrm{~min}$ before immersing them into the liquid nitrogen [20].

\section{Sperm motility, viability, and morphology}

Sperms concentration and general motility were tested using computer-assisted semen analysis (IVOS Hamilton Thorne Biosciences, USA version 12.2). Semen sample viability and morphology were measured by eosin-nigrosin stain [20]. A smear was made from one drop $(10 \mu \mathrm{l})$ of semen and three drops $(30 \mu \mathrm{l})$ of the stain on a warm slide. The stained slide was viewed under a phase-contrast microscope at $400 \times$ magnification, and total of 200 sperm was calculated in an average of four microscopic fields. Sperm that did not absorb the eosin-nigrosin stain was considered alive, whereas those that absorbed the stain were dead [13]. Sperm morphology was examined by the same slide that was used for viability evaluation. The percentage of normal sperm cells was evaluated from 200 sperm cells examined.

\section{Plasma membrane integrity}

The plasma membrane integrity was examined by hypo-osmotic swelling test as described by Kaka et al. [22]. $100 \mu \mathrm{l}$ of semen were mixed with $1 \mu \mathrm{l}$ of hypo-osmotic solution (7.35 g trisodium citrate and $13.51 \mathrm{~g}$ fructose dissolved in $1 \mathrm{~L}$ distilled water; osmolarity of $150 \mathrm{mOsm} / \mathrm{kg}$.) and kept for $1 \mathrm{~h}$ at $37^{\circ} \mathrm{C}$. After that, $15 \mu \mathrm{l}$ of the solution was put on a prewarmed slide covered with a cover slip and sperms were assessed under a phase-contrast microscope at $400 \times$ magnification. A total of 200 spermatozoa per slide were calculated from four different microscopic fields and expressed in percentage. The swelled spermatozoa were considered normal sperm cells that in response to the hypo-osmotic test solution.

\section{Acrosome integrity}

Intact acrosome was evaluated by semen smear mixed with eosin-nigrosin stain and tested under a light microscope at $1000 \times$ magnification oil immersion as 
Table-1: Characteristic of diluting media used in this experiment ( $2 \% \mathrm{VCO}+\mathrm{SL} \%)$.

\begin{tabular}{|c|c|}
\hline Treatments & $\begin{array}{l}\text { Components of diluting } \\
\text { medium }\end{array}$ \\
\hline $\begin{array}{l}\text { Control (C+) (20\% egg } \\
\text { yolk) }\end{array}$ & $\begin{array}{l}\text { Tris-based } \\
\text { extender (Amirat-Briand et al., } \\
\text { 2010) }\end{array}$ \\
\hline Control (C-) (2\% VCO) & Tris $+2 \%$ VCO \\
\hline Treatment 1 & Tris + (1\% SL+2\% VCO $)$ \\
\hline Treatment 2 & Tris $+(1.25 \% \mathrm{SL}+2 \%$ VCO $)$ \\
\hline Treatment 3 & Tris $+(1.5 \% \mathrm{SL}+2 \% \mathrm{VCO})$ \\
\hline Treatment 4 & Tris $+(1.75 \%$ SL+2\% VCO $)$ \\
\hline
\end{tabular}

$\mathrm{VCO}=$ Virgin coconut oil, $\mathrm{SL}=$ Soybean lecithin

developed by Yildiz et al. [23]. 200 spermatozoa were examined for either intact acrosome or detached.

\section{Lipid peroxidation (LPO) test}

Thiobarbituric acid reaction substances (TBARs) were used to measure the LPO as described by Kaka et al. [24]. A total of $500 \mu \mathrm{l}$ of sperm was blended with TBARs solution and after that boiled in a water bath at $95^{\circ} \mathrm{C}$ for $1 \mathrm{~h}$ till the combination looked pink. Subsequent to cooling, $1 \mu \mathrm{l}$ of distilled water and $3 \mu \mathrm{l}$ of n-butanol were supplemented with the mixture and then vortexed. The combinations were centrifuged at $5000 \mathrm{rpm}$ for $10 \mathrm{~min}$. The absorbance of the supernatant was read against an appropriate blank at $532 \mathrm{~nm}$ by spectrophotometer (Secomam, Domont, France). The malondialdehyde (MDA) was calculated from a standard curve of 1, 1, 3, 3-tetraethoxypropane and expressed as $\mathrm{nmol} / 3 \times 10^{8}$ sperm.

\section{Statistical analysis}

Using the PROC UNIVARIATE method, the data normality was checked, and all parameters were found to fit the normal distribution. Data on the effect of various percentages of SL on the semen quality parameters chilled or frozen-thawed in Tris-based extenders containing 2\% VCO and MDA were analyzed using one-way ANOVA with the general linear model method of the SAS version 9.2. Comparisons between various percentage means were analyzed using Duncan multiple range test following significant F-test in ANOVA. All statistical procedures were performed at 95\% confidence level.

\section{Results}

The effects of different concentrations of SL in $2 \%$ VCO contained Tris-based extenders on chilled sperm quality parameters are shown in Table-2. The outcomes showed that after $24 \mathrm{~h}$ the general sperm motility, viability, morphology, membrane integrity, and acrosome integrity, improved with the increase in the SL concentration from $1 \%$ to $1.75 \%$. Furthermore, all the treated groups except the negative control group $(\mathrm{C}-)(2 \% \mathrm{VCO})$ (which is considered less than the treatment groups and the $\mathrm{C}^{+}(20 \%$ egg yolk)) were significantly higher than the control group $(\mathrm{C}+)$. The results showed after 24,72 , and $144 \mathrm{~h}$ indicated that the treatment group with $1.5 \%$ SL was significantly

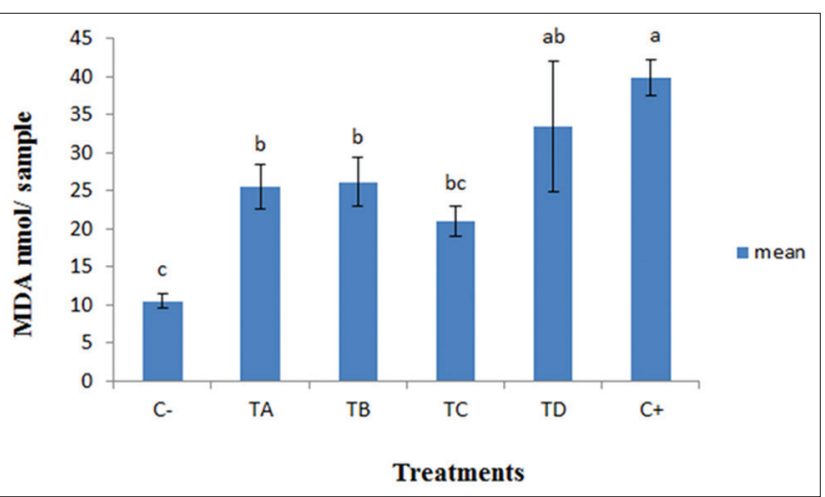

Figure-1: Malondialdehyde level in different concentrations of soybean lecithin (SL) $\%+2 \%$ virgin coconut oil (VCO) assessed by thiobarbituricacid reaction test (mean \pm standard error of mean). $a, b, c$ Denote significant differences $(p<0.05)$, error bar $=\mathrm{SEM}$. MDA $=$ Malondialdehyde, $\mathrm{C}-=0 \% \mathrm{SL}$ with $2 \%$ VCO in Tris-based extender, TA $=1 \%$ SL with $2 \%$ VCO in Tris-based extender, $\mathrm{TB}=1.25 \% \mathrm{SL}$ with $2 \% \mathrm{VCO}$ in Tris-based extender, TC $=1.5 \% \mathrm{SL}$ with $2 \%$ VCO in Trisbased extender, TD $=1.75 \%$ SL with $2 \%$ VCO in Tris-based extender, $\mathrm{C}+=20 \%$ egg yolk in Tris-based extender.

higher than all other treated groups in term of general motility, morphology, viability, membrane integrity, and acrosome integrity. Moreover, there was an interaction between the treatments and time (storage period) on chilled semen in term of general motility, viability, membrane integrity, and acrosome integrity.

Table- 3 shows the effects of the various concentrations of SL and $2 \% \mathrm{VCO}$ on frozen-thawed sperm quality parameters. The positive control group $(20 \%$ egg yolk) $(\mathrm{C}+)$ was better than all treatment groups and negative control $(\mathrm{C}-)$ for all quality parameters. Moreover, there were no differences between 7 and 14 days (storage period) in term of quality parameters in frozen-thawed semen. Furthermore, there was no interaction between the treatment and time of storage period on the frozen-thawed semen.

LPO measured based on the MDA produced is shown in Figure-1. The graph showed that the MDA production was increased in treated groups of SL\% with $2 \% \mathrm{VCO}$ and it was higher in the positive control group (20\% egg yolk). However, the production of MDA was decreased in the negative control group $(0 \% \mathrm{SL}$ with $2 \% \mathrm{VCO})(\mathrm{C}-)$.

\section{Discussion}

In this study, the addition of different concentrations of SL with $2 \%$ VCO in Tris-based extender showed positive effects on the quality of chilled semen parameters such as motility, morphology, viability, membrane integrity, and acrosome integrity. Furthermore, the results showed that after 24, 72, and $144 \mathrm{~h}$ the treatment group of $1.5 \% \mathrm{SL}$ with $2 \% \mathrm{VCO}$ in Tris-based extender was significantly higher in the quality parameters of chilled semen than all other treated groups and the $\mathrm{C}+(20 \%$ egg yolk). This result coincides with earlier study which confirmed that the addition of soybean milk in the diluted buffalo 
Table-2: Effect of different concentrations of SL and VCO in Tris-based extender on bull's post-chilled sperm parameters after 24, 72, and $144 \mathrm{~h}$ (Mean \pm SEM).

\begin{tabular}{|c|c|c|c|c|c|c|}
\hline \multirow{2}{*}{$\frac{\text { Treatments }}{\text { vcO\% SL\% }}$} & \multicolumn{6}{|c|}{ Parameters } \\
\hline & Time of chilling (h) & Motility\% & Morphology $\%$ & Viability\% & $\begin{array}{c}\text { Membrane } \\
\text { integrity \% }\end{array}$ & $\begin{array}{l}\text { Acrosome } \\
\text { integrity\% }\end{array}$ \\
\hline C- & 24 & $11.25 \pm 2.83^{d}$ & $98.54 \pm 0.45$ & $10.00 \pm 2.76^{d}$ & $8.50 \pm 1.90^{c}$ & $61.17 \pm 1.62^{c}$ \\
\hline TA & 24 & $76.08 \pm 1.80^{\mathrm{b}}$ & $97.75 \pm 0.55$ & $72.42 \pm 1.86^{b}$ & $69.75 \pm 1.43^{\mathrm{ab}}$ & $86.79 \pm 1.14^{a}$ \\
\hline TB & 24 & $81.00 \pm 1.58^{\mathrm{ab}}$ & $98.00 \pm 0.42$ & $76.00 \pm 1.70^{\mathrm{ab}}$ & $72.08 \pm 1.45^{\mathrm{a}}$ & $86.46 \pm 1.71^{a}$ \\
\hline $\mathrm{TC}$ & 24 & $83.58 \pm 1.70^{a}$ & $97.46 \pm 0.54$ & $79.75 \pm 1.38^{a}$ & $74.13 \pm 1.66^{a}$ & $86.67 \pm 1.45^{a}$ \\
\hline TD & 24 & $82.42 \pm 1.09^{a}$ & $97.77 \pm 0.38$ & $77.88 \pm 1.10^{a}$ & $72.42 \pm 0.98^{a}$ & $87.75 \pm 1.33^{a}$ \\
\hline $\mathrm{C}+$ & 24 & $68.92 \pm 1.70^{c}$ & $98.25 \pm 0.33$ & $67.04 \pm 1.61^{c}$ & $65.83 \pm 1.23^{b}$ & $77.92 \pm 0.98^{b}$ \\
\hline$C-$ & 72 & $10.25 \pm 2.84^{c}$ & $98.33 \pm 0.36$ & $7.71 \pm 2.27^{c}$ & $6.67 \pm 2.29^{c}$ & $63.88 \pm 2.58^{\mathrm{b}}$ \\
\hline TA & 72 & $58.67 \pm 2.58^{\mathrm{b}}$ & $98.29 \pm 0.42$ & $56.50 \pm 2.32^{b}$ & $54.83 \pm 2.54^{b}$ & $73.25 \pm 1.82^{a}$ \\
\hline TB & 72 & $63.50 \pm 3.18^{\mathrm{ab}}$ & $98.17 \pm 0.33$ & $59.29 \pm 2.42^{\mathrm{ab}}$ & $58.71 \pm 2.73^{\mathrm{ab}}$ & $77.50 \pm 1.76^{a}$ \\
\hline TC & 72 & $69.25 \pm 2.38^{a}$ & $97.96 \pm 0.38$ & $64.83 \pm 2.03^{a}$ & $62.29 \pm 2.14^{a}$ & $75.50 \pm 1.99^{a}$ \\
\hline TD & 72 & $62.75 \pm 2.58^{\mathrm{ab}}$ & $98.29 \pm 0.33$ & $58.58 \pm 1.86^{\mathrm{ab}}$ & $59.13 \pm 2.24^{\mathrm{ab}}$ & $74.46 \pm 1.49^{a}$ \\
\hline $\mathrm{C}+$ & 72 & $62.67 \pm 2.00^{\mathrm{ab}}$ & $98.33 \pm 0.28$ & $60.46 \pm 1.41^{\mathrm{ab}}$ & $59.67 \pm 1.68^{\mathrm{ab}}$ & $72.00 \pm 1.39^{a}$ \\
\hline $\mathrm{C}-$ & 144 & $1.42 \pm 0.67^{\mathrm{d}}$ & $98.71 \pm 0.40$ & $1.79 \pm 0.62^{c}$ & $1.42 \pm 0.38^{c}$ & $58.08 \pm 1.25^{c}$ \\
\hline TA & 144 & $31.83 \pm 1.66^{\mathrm{abc}}$ & $98.25 \pm 0.51$ & $27.42 \pm 0.97^{\mathrm{ab}}$ & $27.04 \pm 1.47^{\mathrm{ab}}$ & $64.71 \pm 1.37^{a}$ \\
\hline TB & 144 & $33.67 \pm 1.69^{a b}$ & $98.38 \pm 0.32$ & $27.59 \pm 1.39^{\mathrm{ab}}$ & $28.46 \pm 1.57^{\mathrm{ab}}$ & $63.92 \pm 1.48^{\mathrm{ab}}$ \\
\hline $\mathrm{TC}$ & 144 & $36.50 \pm 1.72^{a}$ & $98.33 \pm 0.31$ & $30.42 \pm 2.18^{a}$ & $31.08 \pm 1.57^{a}$ & $63.00 \pm 1.20^{\mathrm{ab}}$ \\
\hline TD & 144 & $31.00 \pm 1.91^{\mathrm{bc}}$ & $98.21 \pm 0.29$ & $26.67 \pm 1.84^{\mathrm{ab}}$ & $27.00 \pm 1.96^{\mathrm{ab}}$ & $60.08 \pm 1.20^{\mathrm{bc}}$ \\
\hline $\mathrm{C}+$ & 144 & $28.67 \pm 1.72^{c}$ & $98.75 \pm 0.31$ & $24.75 \pm 1.59^{b}$ & $25.00 \pm 1.77^{b}$ & $60.92 \pm 1.92^{\mathrm{abc}}$ \\
\hline \multirow[t]{3}{*}{$p$ value } & Treatments & 0.0001 & 0.3840 & 0.0001 & 0.0001 & 0.0001 \\
\hline & Time & 0.0001 & 0.1095 & 0.0001 & 0.0001 & 0.0001 \\
\hline & Treatments*Time & 0.0001 & 0.9949 & 0.0001 & 0.0001 & 0.0001 \\
\hline
\end{tabular}

$a, b, c, d$ Values with different superscripts within column at the same time show a significant difference at $p<0.05$.

$\mathrm{VCO}=$ Virgin coconut oil, SL=Soybean lecithin, $\mathrm{C}-=0 \% \mathrm{SL}$ with $2 \% \mathrm{VCO}$ in Tris-based extender, TA=1\% SL with $2 \%$ VCO in Tris-based extender, TB $=1.25 \%$ SL with $2 \%$ VCO in Tris-based extender, TC $=1.5 \%$ SL with $2 \%$ VCO in Tris-based extender, TD $=1.75 \%$ SL with $2 \%$ VCO in Tris-based extender, C $+=20 \%$ egg yolk in Tris-based extender, SEM=Standard error of mean

Table-3: Effect of different concentrations of SL and VCO in Tris-based extender on bull's post- thawed sperm parameters after 7 and 14 days (mean \pm SEM).

\begin{tabular}{lcccccc}
\hline Treatments & \multicolumn{5}{c}{ Parameters } \\
\cline { 1 - 6 } VCO\% SL\% & $\begin{array}{c}\text { Time of } \\
\text { freezing (days) }\end{array}$ & Motility \% & Morphology \% & Viability \% & $\begin{array}{c}\text { Membrane } \\
\text { integrity \% }\end{array}$ & $\begin{array}{c}\text { Acrosome } \\
\text { integrity \% }\end{array}$ \\
\hline C- & 7 & $3.17 \pm 1.22^{\mathrm{b}}$ & $98.25 \pm 0.29$ & $9.29 \pm 1.36^{\mathrm{c}}$ & $2.83 \pm 1.03^{\mathrm{b}}$ & $63.88 \pm 1.41^{\mathrm{b}}$ \\
TA & 7 & $13.92 \pm 4.48^{\mathrm{b}}$ & $97.17 \pm 0.69$ & $28.83 \pm 5.96^{\mathrm{b}}$ & $12.88 \pm 4.07^{\mathrm{b}}$ & $69.54 \pm 1.40^{\mathrm{b}}$ \\
TB & 7 & $13.92 \pm 4.51^{\mathrm{b}}$ & $97.54 \pm 0.39$ & $29.54 \pm 5.59^{\mathrm{b}}$ & $12.71 \pm 4.18^{\mathrm{b}}$ & $68.63 \pm 2.02^{\mathrm{b}}$ \\
TC & 7 & $10.00 \pm 4.01^{\mathrm{b}}$ & $97.96 \pm 0.50$ & $23.83 \pm 6.27^{\mathrm{b}}$ & $8.92 \pm 3.67^{\mathrm{b}}$ & $67.88 \pm 2.03^{\mathrm{b}}$ \\
TD & 7 & $9.33 \pm 3.04^{\mathrm{b}}$ & $97.92 \pm 0.46$ & $22.54 \pm 5.35^{\mathrm{bc}}$ & $7.88 \pm 2.58^{\mathrm{b}}$ & $63.08 \pm 5.86^{\mathrm{b}}$ \\
C+ & 7 & $51.17 \pm 2.85^{\mathrm{a}}$ & $98.29 \pm 0.32$ & $56.04 \pm 1.98^{\mathrm{a}}$ & $50.25 \pm 2.71^{\mathrm{a}}$ & $85.63 \pm 1.32^{\mathrm{a}}$ \\
C- & 14 & $2.67 \pm 0.98^{\mathrm{c}}$ & $98.50 \pm 0.28$ & $8.42 \pm 0.82^{\mathrm{c}}$ & $2.46 \pm 0.82^{\mathrm{b}}$ & $65.58 \pm 1.56^{\mathrm{b}}$ \\
TA & 14 & $13.25 \pm 4.14^{\mathrm{b}}$ & $97.78 \pm 0.52$ & $28.46 \pm 5.60^{\mathrm{b}}$ & $12.00 \pm 3.71^{\mathrm{b}}$ & $68.63 \pm 2.02^{\mathrm{b}}$ \\
TB & 14 & $12.50 \pm 4.24^{\mathrm{bc}}$ & $98.00 \pm 0.32$ & $27.71 \pm 5.09^{\mathrm{b}}$ & $11.92 \pm 3.98^{\mathrm{b}}$ & $67.83 \pm 2.35^{\mathrm{b}}$ \\
TC & 14 & $9.00 \pm 3.86^{\mathrm{b}}$ & $97.96 \pm 0.50$ & $21.88 \pm 5.96^{\mathrm{b}}$ & $8.33 \pm 3.48^{\mathrm{b}}$ & $68.21 \pm 2.24^{\mathrm{b}}$ \\
TD & 14 & $8.67 \pm 2.87^{\mathrm{bc}}$ & $98.08 \pm 0.39$ & $19.17 \pm 4.69^{\mathrm{bc}}$ & $9.79 \pm 4.37^{\mathrm{b}}$ & $67.75 \pm 1.62^{\mathrm{b}}$ \\
C+ & 14 & $50.33 \pm 2.79^{\mathrm{a}}$ & $98.46 \pm 0.26$ & $55.79 \pm 2.27^{\mathrm{a}}$ & $50.17 \pm 2.63^{\mathrm{a}}$ & $84.46 \pm 1.08^{\mathrm{a}}$ \\
P value & Treatments & 0.0001 & 0.2600 & 0.0001 & 0.0001 & 0.0001 \\
& Time & 0.6716 & 0.1617 & 0.5932 & 0.9449 & 0.6590 \\
& Treatments*Time & 1.0000 & 0.9880 & 0.9995 & 0.9984 & 0.8226 \\
\hline
\end{tabular}

$a, b, c$ Values with different superscripts within column at the same time show a significant difference at $p<0.05$. VCO $=$ Virgin coconut oil, SL=Soybean lecithin, $\mathrm{C}-=0 \% \mathrm{SL}$ with $2 \%$ VCO in Tris-based extender, TA $=1 \%$ SL with $2 \%$ VCO in Tris-based extender, $\mathrm{TB}=1.25 \% \mathrm{SL}$ with $2 \%$ VCO in Tris-based extender, TC $=1.5 \%$ SL with $2 \%$ VCO in Tris-based extender, $\mathrm{TD}=1.75 \% \mathrm{SL}$ with $2 \%$ VCO in Tris-based extender, $\mathrm{C}+=20 \%$ egg yolk in Tris-based extender, SEM=Standard error of mean

semen enhanced chilled semen characteristics [1]. According to De Paz et al. [25], who reported that the SL extender could improve the motility and viability of chilled ram semen in 15 and $5^{\circ} \mathrm{C}$ which was equally effective to egg yolk extender. Akhter et al. [26] indicated that the semen motility and viability of buffalo sperms chilled at $5^{\circ} \mathrm{C}$ in SL based extender were better than in other with respect to extender such as milk, Tris-citric egg yolk, and egg yolk-citrate extender. Moreover, Rehman et al. [27] reported that 25\% soy milk could be utilized as a substitute of traditional egg yolk-based extender for bovine sperm stored at $4^{\circ} \mathrm{C}$. It is important to mention that the mixture of $1.5 \%$ SL with 2\% VCO (in Tris--based extender) contains 
phospholipids, different types of the fatty acids, and antioxidants could play a great role to maintain the structure of sperm plasma membrane against cold shock and thus, improved the quality parameters of the sperm. Zhang et al. [10] explained that the better enhancement of semen parameters in SL supplemented extender is the result of its little viscosity and a lesser amount of debris. The phospholipids in SL may be replaced the phospholipids of the sperm membrane and as result of that the structure and function of sperm are maintained $[28,29]$. Furthermore, the phospholipids from soybean along with these of the sperm membrane would form a protective membrane against the harmful elements [10].

In this study, the supplementation of different concentrations of SL with $2 \% \mathrm{VCO}$ in Tris-based semen extender did not improve the quality of frozen-thawed semen parameter. In contrast, the group (20\% egg yolk) $(\mathrm{C}+)$ improved motility, morphology, viability, membrane integrity, and acrosome integrity of the frozen-thawed semen. This finding supports a previous study by Crespilho et al. [5], who reported that the soy lecithin represents a substitute for the growth of chemically defined extenders with reduced hygienic risk of contamination. However, egg yolk based extenders are more useful on the cryopreservation of bull post-thaw semen viability and fertility. Furthermore, De Leeuw et al. [30] reported that bovine spermatozoa survive freezing more efficiently in egg yolk-containing extenders than in SL. Frozen-thawed semen recovery was significantly better when the sperm was cryopreserved in egg yolkbased extender compared to lecithin-based extender. The beneficial outcome of egg yolk may be related to its cryoprotective abilities and nutritive properties [31]. On the other hand, SL lost its emulsification properties as the sperm is frozen. This is because $\mathrm{SL}$ is insoluble in water solutions and creates emulsions. This property of SL is a proven obstacle in the use of such extenders after hours or days of storage at $5^{\circ} \mathrm{C}$ and $15^{\circ} \mathrm{C}$, which is essential in the field when chilled semen is used in artificial insemination. The conditions of the temperature, procedures of preparation, and time of storage may affect the formation of emulsions and availability of phospholipids in the extender [25]. Moreover, it was observed decrease of phospholipids whenever extenders reach storage temperatures of between $15^{\circ} \mathrm{C}$ and $5^{\circ} \mathrm{C}$ after a few hours. This is clarified by increased the viscosity of the extender which thought to be induced by the low temperature [32]. Moreover, Crespilho et al. [33] and Papa et al. [34] reported that the protective efficiency of SL during the freezing process of semen is limited which resulted in reduction in bovine frozen-thawed sperm survivability and fertility when compared with egg yolk-based extenders. Furthermore, according to van Wagtendonk-de Leeuw et al. [35], it has been reported that the influence of SL on sperm motility results from the extender viscosity and the presence of particulate debris. In addition, Üstüner et al. [36] suggested that the frozen-thawed method damagingly affected sperm motility and acrosome integrity.

The present results show that the MDA level in the extender of different concentrations of SL with $2 \% \mathrm{VCO}$ in Tris-based extender was significantly lower than the positive group containing $20 \%$ egg yolk $(\mathrm{C}+)$. These findings substantiate results of previous studies, which showed that the components of extender effect the cryopreserved semen lipid peroxidation (LPO) [37,38]. It appears that in the present study, $2 \%$ VCO with the different concentrations of SL $(1 \%, 1.25 \%, 1.5 \%$, and $1.75 \%$ ) protected sperm positively from LPO when compared to $20 \%$ of egg yolk (C+). The reason is that the structure of egg yolk contains more unsaturated fatty acid susceptible to LPO. However, this study incongruent with that of Çoyan et al. [39] and Atessahin et al. [40] who reported that sperm LPO is not influenced freezing extender. The lowest level of MDA was recorded in the (C-) $(2 \% \mathrm{VCO})$ group. This group is produced low amount of MDA because it contained only $2 \% \mathrm{VCO}$ (it has plenty of different types of antioxidants) and free from any type of cryoprotectants and that was the reason of low sperm parameters in this group.

\section{Conclusion}

This study indicated that the supplementation of different concentration of SL in Tris-based semen extender (containing 2\% VCO) enhanced quality parameters of chilled bull semen. Moreover, the result also demonstrated that optimal SL concentration in the extended medium was $1.5 \%$ for chilled bull semen. The Tris-based extender containing 2\% VCO with different concentrations of SL\% did not improve the quality parameters of frozen-thawed bull semen. Further investigations are required to enhance the freezing process using a better solvent that may improve homogenization of VCO with SL combination in extenders.

\section{Authors' Contributions}

AAT, HW, and YMG were designed all steps of the study. AAT, FHB, HS, AMK, and MAA have collected samples of the semen and evaluated throughout the study. AAT and ME have analyzed the data statistically. AAT, HW, YR, NY, and YMG have prepared the tables of results and discussed it. AAT wrote the manuscript draft, and all authors have read, revised, and approved the final manuscript.

\section{Acknowledgments}

The first author wish to acknowledge the support of University of Khartoum, Sudan for awarding the scholarship, the administration and staff of UPM farm and theriogenology and cytogenetics laboratory of the Faculty of Veterinary Medicine (UPM) for their collaboration throughout this project. This study was 
supported by the Universiti Putra Malaysia (Grant \#UPM-9492800).

\section{Competing Interests} interests

The authors declare that they have no competing

\section{References}

1. Singh, A., Singh, V., Narwade, B., Mohanty, T. and Atreja, S. (2012) Comparative quality assessment of buffalo (Bubalus bubalis) semen chilled $\left(5^{\circ} \mathrm{C}\right)$ in egg yolk and soya milkbased extenders. Reprod. Domest. Anim., 47(4): 596-600.

2. Verberckmoes, S., Van Soom, A., Dewulf, J. and de Kruif, A. (2005) Comparison of three diluents for the storage of fresh bovine semen. Theriogenology, 63(3): 912-922.

3. Vishwanath, R. and Shannon, P. (2000) Storage of bovine semen in liquid and frozen state. Anim. Reprod. Sci., 62(1): 23-53.

4. Bucher, A., Kasimanickam, R., Hall, J.B., Dejarnette, J.M., Whittier, W.D., Kähn, W. and Xu, Z. (2009) Fixed-time AI pregnancy rate following insemination with frozen-thawed or fresh-extended semen in progesterone supplemented CO-synch protocol in beef cows. Theriogenology, 71(7): 1180-1185.

5. Crespilho, A.M., Sá Filho, M.F., Dell'Aqua, J.A., Nichi, M., Monteiro, G.A., Avanzi, B.R., Martins, A. and Papa, F.O. (2012) Comparison of in vitro and in vivo fertilizing potential of bovine semen frozen in egg yolk or new lecithin based extenders. Livest. Sci., 149(1): 1-6.

6. Ansari, M.S., Rakha, B.A., Ullah, N., Andrabi, S.M.H. and Akhtar, S. (2012) Glutathione addition in Tris-citric egg yolk extender improves the quality of cooled buffalo (Bubalus bubalus) bull semen. Pak. J. Zool., 43: 49-55.

7. Thun, R., Hurtado, M. and Janett, F. (2002) Comparison of biociphos-plus ${ }^{\circledR}$ and Tris-egg yolk extender for cryopreservation of bull semen. Theriogenology, 57(3): 1087-1094.

8. Aires, V.A., Hinsch, K.D., Mueller-Schloesser, F., Bogner, K., Mueller-Schloesser, S. and Hinsch, E. (2003) In vitro and in vivo comparison of egg yolk-based and soybean lecithin-based extenders for cryopreservation of bovine semen. Theriogenology, 60(2): 269-279.

9. Fukui, Y., Kohno, H., Togari, T., Hiwasa, M. and Okabe, K. (2008) Fertility after artificial insemination using a soybean-based semen extender in sheep. J. Reprod. Dev., 54(4): 286-289.

10. Zhang, S., Hu, J., Li, Q., Jiang, Z. and Zhang, X. (2009) The cryoprotective effects of soybean lecithin on boar spermatozoa quality. Afr. J. Biotechnol., 8(22): 6476-6480.

11. Trotta, M., Pattarino, F. and Ignoni, T. (2002) Stability of drug-carrier emulsions containing phosphatidylcholine mixtures. Eur. J. Pharm. Biopharm., 53(2): 203-208.

12. Memon, A.A., Wahid, H., Rosnina, Y., Goh, Y.M., Ebrahimi, M., Nadia, F.M. and Audrey, G. (2011) Effect of butylated hydroxytoluene on cryopreservation of Boer goat semen in Tris egg yolk extender. Anim. Reprod. Sci., 129: 44-49.

13. Memon, A.A., Wahid, H., Rosnina, Y., Goh, Y.M., Ebrahimi, M. and Nadia, F. (2012) Effect of antioxidants on post-thaw microscopic, oxidative stress parameter and fertility of Boer goat spermatozoa in Tris egg yolk glycerol extender. Anim. Reprod. Sci., 136(1): 55-60.

14. Nasiri, A.H., Towhidi, A. and Zeinoaldini, S. (2012) Combined effect of DHA and $\alpha$ tocopherol supplementation during bull semen cryopreservation on sperm characteristics and fatty acid composition. Andrologia, 44(1): 550-555.

15. Bucak, M.N., Ateşşahin, A., Varışlı, Ö., Yüce, A., Tekin, N. and Akçay, A. (2007) The influence of trehalose, taurine, cysteamine and hyaluronan on ram semen: Microscopic and oxidative stress parameters after freeze-thawing process. Theriogenology, 67(5): 1060-1067.
16. Marina, A., Man, Y.C., Nazimah, S. and Amin, I. (2009) Antioxidant capacity and phenolic acids of virgin coconut oil. Int. J. Food Sci. Nutr., 60(2): 114-123.

17. Dosumu, O., Duru, F., Osinubi, A., Oremosu, A. and Noronha, C. (2010) Influence of virgin coconut oil (VCNO) on oxidative stress, serum testosterone and gonadotropic hormones (FSH, LH) in chronic ethanol ingestion. Agric. Biol. J. N. Am., 6: 1126-1132.

18. Nevin, K.G. and Rajamohan, T. (2006) Virgin coconut oil supplemented diet increases the antioxidant status in rats. Food Chem., 99(2): 260-266.

19. Dickinson, E. (1993) Towards more natural emulsifiers. Trends Food Sci. Technol., 4(10): 330-334.

20. Khumran, A.M., Yimer, N., Rosnina, Y., Ariff, M.O., Wahid, H., Kaka, A., Ebrahimi, M. and Sarsaifi, K. (2015) Butylated hydroxytoluene can reduce oxidative stress and improve quality of frozen-thawed bull semen processed in lecithin and egg yolk based extenders. Anim. Reprod. Sci., 163: $128-134$.

21. Amirat-Briand, L., Bencharif, D., Vera-Munoz, O., Pineau, S., Thorin, C., Destrumelle, S., Desherces, S., Anton, M., Jouan, M., Shmitt, E. and Tainturier, D. (2010) In vivo fertility of bull semen following cryopreservation with an LDL (low-density lipoprotein) extender: Preliminary results of artificial inseminations. Anim. Reprod. Sci., 122(3): 282-287.

22. Kaka, A., Wahid, H., Rosnina, Y., Yimer, N., Khumran, A.M., Behan, A.A. and Ebrahimi, M. (2015b) Alpha-linolenic acid supplementation in tris extender can improve frozen-thawed bull semen quality. Reprod. Domest. Anim., 50(1): 29-33.

23. Yildiz, C., Kaya, A., Aksoy, M. and Tekeli, T. (2000) Influence of sugar supplementation of the extender on motility, viability and acrosomal integrity of dog spermatozoa during freezing. Theriogenology, 54(4); 579-585.

24. Kaka, A., Wahid, H., Yimer, N., Khumran, A.M., Kazhal, S., Behan, A.A., Ebrahimi, M. and Ubedullah, K. (2015a) $\alpha$-linolenic acid supplementation in BioXcell ${ }^{\circledR}$ extender can improve the quality of post-cooling and frozen-thawed bovine sperm. Anim. Reprod. Sci., 153: 1-7.

25. De Paz, P., Esteso, M.C., Alvarez, M., Mata, M., Chamorro, C.A. and Anel, L. (2010) Development of extender based on soybean lecithin for its application in liquid ram semen. Theriogenology, 74(4): 663-671.

26. Akhter, S., Ansari, M., Rakha, B., Ullah, N., Andrabi, S. and Khalid, M. (2011) In vitro evaluation of liquid-stored buffalo semen at $5^{\circ} \mathrm{C}$ diluted in soya lecithin based extender (Bioxcell $\left.{ }^{\circledR}\right)$, Tris-citric egg yolk, skim milk and egg yolk-citrate extenders. Reprod. Domest. Anim., 46(1): 45-49.

27. Rehman, F., Qureshi, M. and Khan, R. (2014) Effect of soybean-based extenders on sperm parameters of HolsteinFriesian bull during liquid storage at $4^{\circ} \mathrm{C}$. Pak. J. Zool., 46(1): 185-189.

28. Graham, J.K. and Foote, R.H. (1987) Effect of several lipids, fatty acyl chain length, and degree of unsaturation on the motility of bull spermatozoa after cold shock and freezing. Cryobiology, 24(1): 42-52.

29. Trimeche, A., Anton, M., Renard, P., Gandemer, G. and Tainturier, D. (1997) Quail egg yolk: Anovel cryoprotectant for the freeze preservation of Poitou Jackass sperm. Cryobiology, 34: 385-393.

30. De Leeuw, F., De Leeuw, A., den Daas, J., Colenbrander, B. and Verkleij, A. (1993) Effects of various cryoprotective agents and membrane-stabilizing compounds on bull sperm membrane integrity after cooling and freezing. Cryobiology, 30(1): $32-44$

31. Hafez, E.S.E. (1993) Reproduction in Farm Animals. Vol. 6. Lea and Febiger, Philadelphia. p330-343, 405-424.

32. Badens, E., Magnan, C. and Charbit, G. (2001) Microparticles of soy lecithin formed by supercritical processes. Biotechnol. Bioeng., 72(2): 194-204.

33. Crespilho, A.M., Papa, F.O., Santos, M.D.P. and Sá Filho, M.F.D. (2012) Use of cooled bull semen as a 
strategy to increase the pregnancy rate in fixed-time artificial insemination programs-case report. Am. J. Anim. Vet. Sci., 7(4): 175-179.

34. Papa, F.O., Felıcio, G.B., Melo, C.M., Vita, B., Avanzi, B.R. and Aqua, J.A. (2010) Effect of substituting soybean lecithin for egg yolk in an extender used for the cryopreservation of stallion semen. Anim. Reprod. Sci., 121: 71-72.

35. van Wagtendonk-de Leeuw, A.M., Haring, R.M., KaalLansbergen, L.M.T. and den Daas, J.H.G. (2000) Fertility results using bovine semen cryopreserved with extenders based on egg yolk and soy bean extract. Theriogenology, 54(1): 57-67.

36. Üstüner, B., Alcay, S., Nur, Z., Sağİkaya, H. and Soylu, M.K. (2014), Effect of egg yolk and soybean lecithin on tris-based extender in post-thaw ram semen quality and in vitro fertility. Kafkas Univ. Vet. Fak. Derg., 20(3): 393-398.
37. Salmani, H., Towhidi, A., Zhandi, M., Bahreini, M. and Sharafi, M. (2014) In vitro assessment of soybean lecithin and egg yolk based diluents for cryopreservation of goat semen. Cryobiology, 68(2): 276-280.

38. Bucak, M.N., Tuncer, P.B., Sarı̈̈zkan, S. and Ulutaş, P.A. (2009) Comparison of the effects of glutamine and an amino acid solution on post-thawed ram sperm parameters, lipid peroxidation and antioxidant activities. Small Rumin. Res., 81(1): 13-17.

39. Çoyan, K., Başpınar, N., Bucak, M.N. and Akalın, P.P. (2011) Effects of cysteine and ergothioneine on postthawed Merino ram sperm and biochemical parameters. Cryobiology, 63(1): 1-6.

40. Atessahin, A., Bucak, M.N., Tuncer, P.B. and Kız1l, M. (2008) Effects of antioxidant additives on microscopic and oxidative parameters of Angora goat semen following the freeze-thawing process. Small Rumin. Res., 77(1): 38-44. 